\title{
Analysis of virulence genes in Escherichia coli isolated from grated cheese
}

Pesquisa de genes de virulência em Escherichia coli isolada de queijo ralado

\author{
Rodrigo Prado MARTINS¹, Luciano NAKAZATO², Valéria DUTRA², Domingos da Silva LEITE
}

\begin{abstract}
This research aimed to verify the presence of virulence genes in strains of Escherichia coli isolated from grated cheese sold in farmers' markets of Cuiabá-MT, Brazil. Forty samples of this food were submitted for microbiological analysis and 22 (55\%) tested positive for E. coli. Next, 64 strains of $E$. coli were isolated from the positive samples and screened by the polymerase chain reaction (PCR) for the presence of the genes encoding the following virulence factors: st $x 1$ and st $x 2$ (verotoxin types 1 and 2), eae (intimin), lt1 (heat-labile toxin type 1), st 1 (heat-stable toxin type 1), $c n f 1$ and $c n f 2$ (cytotoxic necrozing factor types 1 and 2), and $c d t B$ (cytolethal distending toxin). All the isolates were negative for the genes $s t x 1$, stx2, eae, lt1, st 1, cnf1, and $c d t B$, and five strains (7.81\%) were positive for $c n f 2$. A low prevalence of $E$. coli positive for virulence factors associated with the pathogenesis of diarrhoea was observed in this study. However, the presence of CNF-2 producing strains and the possibility of occurrence and scattering of other virulence factors that were not surveyed in the work indicate the risk related to the consumption of grated cheese from farmers' markets.

Keywords: Escherichia coli; virulence genes; grated cheese; Cuiabá - MT.
\end{abstract}

\section{Resumo}

Este trabalho teve como objetivo verificar a presença de genes de virulência em linhagens de Escherichia coli isoladas de queijo ralado comercializado em feiras livres de Cuiabá-MT. Quarenta amostras desse alimento foram submetidas a provas microbiológicas, sendo 22 (55\%) positivas para E. coli. Em seguida, 64 isolados de E. coli provenientes das amostras positivas foram testados, por meio da reação da polimerase em cadeia (PCR), para a presença dos genes que codificam os seguintes fatores de virulência: stxle stx2 (verotoxina tipo 1 e 2), eae (intimina), lt1 (toxina termolábil tipo 1), st1 (toxina termoestável tipo 1), cnf1 e cnf2 (fator de necrose citotóxico tipo 1 e 2) e $c d t B$ (toxina citoletal distensora). Todos os isolados analisados foram negativos para os genes $v t 1, v t 2$, eae, $l t 1, s t 1, c n f 1, c d t B$ e cinco $(7,81 \%)$ foram positivos para o gene $c n f 2$. Observou-se uma baixa prevalência de E. coli portadora de fatores de virulência associados à patogênese da diarréia. Entretanto, a presença de linhagens produtoras de CNF-2 e a possibilidade de ocorrência e dispersão de outros fatores de virulência não pesquisados neste estudo apontam para o risco vinculado ao consumo de queijo ralado de origem informal.

Palavras-chave: Escherichia coli; genes de virulência; queijo ralado; Cuiabá - MT.

\section{Introduction}

According to the Brazilian legislation, grated cheese is the product obtained by grating from one or up to four types of cheese suitable for human consumption (BRASIL, 1997). The usage of inappropriate raw material associated with hygiene failures during food manufacturing, storage, and commercialization can result in risk of infection and intoxication to customers (ZAFFARI et al., 2007). However, the sale of grated cheese produced from homemade raw-milk cheese is very common in Brazilian farmers' markets.

The contamination of cheeses with coliforms has been largely reported in Brazil (BRANT et al., 2007; ZAFFARI; MELLO; COSTA, 2007; LOGUERCIO; ALEIXO, 2001). The coliforms colonize the intestinal tract of warm-blooded animals, and Escherichia coli is the most frequent member of this group and some strains are pathogenic for humans and animals. (LOGUERCIO; ALEIXO, 2001).

Diarrhoeagenic E. coli can be grouped into five categories: enterotoxigenic (ETEC), enteropathogenic (EPEC), enterohemorrhagic (EHEC), enteroinvasive (EIEC), and enteroaggregative (EAggEC) (GONZALEZ et al., 2000).

The first group constitutes one of the most important vectors of $E$. coli diarrhoea. ETEC causes diarrhoea by adhering to the intestinal mucosa through its unique colonization factors and produces either heat-labile enterotoxins (LT-I and LT-II) or heat-stable enterotoxins (STa and STb), or both (PANETO et al., 2007). Virulent EPEC often exhibit a typical adherence phenotype to epithelial cells (localized adherence - LA) and induce attaching-effacing (A/E) lesions on gut enterocytes. The virulence genes eaf and eae are associated with these features (GONZALEZ et al., 2000). Shiga toxin-producing E. coli strains (STEC) are defined by the production of Shiga toxin (Stx) or possession of the Stx encoding gene subtype stx 1 and stx2, or both st $x 1$ and stx2. Highly human-virulent STEC strains are also called enterohemorrhagic E. coli (EHEC) strains (BEUTIN et al., 2007).

Recebido para publicação em 11/11/2008

Aceito para publicação em 31/10/2009 (003944)

${ }^{1}$ Departamento de Ciências Básicas e Produção Animal, Universidade Federal de Mato Grosso - UFMT

${ }^{2}$ Departamento de Clínica Médica Veterinária, Universidade Federal de Mato Grosso - UFMT

3 Departamento de Microbiologia e Imunologia, Instituto de Biologia, Universidade Estadual de Campinas - UNICAMP,

Cidade Universitária Zeferino Vaz, Barão Geraldo, CP 6109, CEP 13083-970, Campinas - SP, Brasil, E-mail: domingos@unicamp.br

${ }^{*}$ A quem a correspondencia deve ser enviada 
There is a close association between the development of human diseases and the presence of additional virulence markers. One of those markers is the eae gene, which encodes an outer membrane protein required for intimate attachment to the host intestinal mucosa (COBBOLD; DESMARCHELIER, 2001). The necrotoxigenic E. coli (NTEC) produce the Cytotoxic Necrozing Factor (CNF) type 1 and 2 and have been implicated in opportunistic diarrhoeal diseases in humans (QUINTO; CEPADA, 1997). Cytolethal distending toxin (CDT) is a potent bacterial exotoxin that has dramatic effects on target cells in culture. Previous studies suggest that CDT also may be a virulence factor in vivo (CLARK et al., 2002).

Soft and semi-soft cheeses have been previously associated with disease outbreaks involving pathogenic strains of $E$. coli (PANETO et al., 2007; QUINTO; CEPEDA, 1997). However, little information about the presence of these microorganisms in grated cheese is available. Given these considerations, this study aimed to verify the prevalence of genes encoding virulence factors in strains of $E$. coli isolated from grated cheese commercialized in farmers' markets.

\section{Materials and methods}

Forty samples of grated cheese were collected from farmers' markets located in Cuiabá-MT, Brazil. The samples were kept in sterile plastic bags and carried under refrigeration to the Laboratory of Veterinary Microbiology of the College of Agronomic Sciences and Veterinary Medicine, Federal University of Mato Grosso - UFMT.

A $25 \mathrm{~g}$ portion of each sample was blended with $225 \mathrm{~mL}$ of peptone water and incubated at $37^{\circ} \mathrm{C}$ for 24 hours. Afterwards, $10 \mu \mathrm{l}$ of the culture were streaked onto MacConkey agar (Oxoid, United Kingdom) plates and incubated at $37^{\circ} \mathrm{C}$ for 24 hours. Three colonies from each plate with typical E. coli morphology were selected and examined by the EPM-medium (TOLEDO; FONTES; TRABULSI, 1982a), MILi (TOLEDO; FONTES; TRABULSI, 1982b), and citrate test (HOLT; KRIEG, 1984) to confirm the identification.

The strains confirmed as E. coli were screened for the presence of virulence genes by the PCR technique.

For DNA extraction, one loop of bacterial growth obtained by incubation on Trypticase Soy Agar (Oxoid, United Kingdom) at $37^{\circ} \mathrm{C}$ for 24 hours was suspended in $100 \mu$ of sterile UHQ water, boiled for 10 minutes, and centrifuged at $10.000 \times \mathrm{g}$ for 2 minutes. The supernatant was used as the template in the PCR assays.
The PCR was carried out using oligonucleotide primers for the following genes: stx 1 and stx 2 (verotoxin types 1 and 2), eae (intimin), lt1 (heat-labile toxin type 1), st 1 (heat-stable toxin type 1), cnf1 e cnf2 (cytotoxic necrozing factor types 1 and 2), and $c d t B$ (cytolethal distending toxin).

The PCR mixture ( $30 \mu \mathrm{l}$ ) was prepared using $3 \mu \mathrm{L}$ of $10 \mathrm{X}$ PCR buffer (Fermentas, United States), $2.4 \mu \mathrm{L}$ of $25 \mathrm{mM} \mathrm{MgCl} 2$ (Fermentas, United States), $0.24 \mu \mathrm{L}$ of $25 \mathrm{mM}$ dNTP mixture (Fermentas, United States), $0.3 \mu \mathrm{L}$ of Taq DNA polymerase (5U/ $\mu \mathrm{L}$ Fermentas, United States), sterile UHQ water (qsp), $7 \mu \mathrm{L}$ of template DNA, and forward and reverse primers ( $1 \mu \mathrm{L}$ each). The concentration of the primers, annealing temperatures, and predicted sizes of the amplified products are shown in Table 1.

Amplifications were executed in a thermal cycler (GeneAmp ${ }^{\circ}$ PCR System 9700, Applied Biosystems, United States) according to the following conditions: initial denaturation at $94^{\circ} \mathrm{C}$ for 10 minutes, 30 cycles $\left(94^{\circ} \mathrm{C}\right.$ for 1 minute, annealing temperature according to Table 1 for 1 minute, $72{ }^{\circ} \mathrm{C}$ for $2^{\prime}$ ), and final extension at $72{ }^{\circ} \mathrm{C}$ for 2 minutes. E. coli $\mathrm{K} 12 \mathrm{C} 600$ was used as a negative control of the reactions, and the following strains were used as positive controls: $\mathrm{H} 30$ (O26:H11 stx1) J2 (O157:H- stx2 and eae), H100407 (lt1 and st1), MR48 (cnf-1), B26a (cnf2), and CLDT7 (2) ( $c d t B)$.PCR products were analysed by agarose gel electrophoresis and observed under UV light at a wavelength of $420 \mathrm{~nm}$ after ethidium bromide staining.

\section{Results and discussion}

Among the 40 samples analyzed, 22 (55\%) were positive for E. coli and 64 strains of this microorganism were isolated from those samples. Pimentel (2002) evaluated the microbiological quality of 18 different brands of grated cheese produced under Brazilian Federal Inspection (SIF) and observed that all samples analyzed were negative for coliforms. According to the authors, this result could be correlated to the low water activity, low moisture level, and the presence of preservatives in grated cheese.

The higher level of contamination by E. coli reported in this study can be related to the source of the samples since informal food is more susceptive to contamination during its manufacture, commercialization, and storage. A previous research stated that 93.3\% of raw cheese samples from free markets of Cuiabá - MT had levels of faecal coliforms higher than the limit established by the Brazilian legislation (LOGUERCIO; ALEIXO, 2001). Similar results were observed in other Brazilian regions (BRANT et al., 2007; ZAFFARI; MELLO; COSTA, 2007). The high prevalence

Table 1. Concentration, annealing temperatures of primers, and predicted sizes of the amplified products used in the PCR.

\begin{tabular}{lcccc}
\hline Gene & Concentration $\left(\mathrm{ng} . \mu \mathrm{l}^{-1}\right)$ & Annealing temperature $\left({ }^{\circ} \mathrm{C}\right)$ & Predicted size $(\mathrm{pb})$ & Reference \\
\hline st $x-1$ & 90 & 53 & 364 & Salvadori et al. (2003) \\
stx-2 & 90 & 53 & 386 & Salvadori et al. (2003) \\
eae & 60 & 63 & 384 & Salvadori et al. (2003) \\
lt1 & 90 & 48 & 480 & Salvadori et al. (2003) \\
st1 & 60 & 60 & 244 & Salvadori et al. (2003) \\
cnf1 & 90 & 43 & 543 & Salvadori et al. (2003) \\
cnf2 & 90 & 43 & 543 & Salvadori et al. (2003) \\
cdtB & 60 & 63 & 384 & Silva e Leite (2002) \\
\hline
\end{tabular}


of soft cheeses contaminated by $E$. coli is a public health threat to their customers and a concern for grated cheese production.

Although the dehydration process carried out in the production of grated cheese reduce the susceptibility to bacterial growth, some micro-organisms can tolerate it. Le Magrex-Debar et al. (2000) investigated the recovery of bacteria stressed with dehydration increased in hypersalted mediums and affirmed that $E$. coli seemed protected from dehydration stress. Enteropathogenic E. coli have the ability to grow during the manufacture of cheese and to survive during the ripening of this product (QUINTO; CEPEDA, 1997). Therefore, the presence of $E$ coli in grated cheese represents health hazard for the customers 0 , although the production process can reduce the microorganism charge.

Our analysis of the genes encoding important virulence markers of $E$. coli showed that none of the isolates carried the genes $v t 1$, $v t 2$, eae, $l t 1, s t 1, c n f 1$, and $c d t B$ and only five $(7.81 \%)$ strains were carriers of $c n f 2$. The low prevalence of pathogenic E. coli in cheese, in spite of the large contamination by faecal coliforms, has been previously stated (PANETO et al., 2007; GONZALEZ et al., 2000); it was suggested that pathogenic E. coli could have been present as a small fraction of the coliform population and could have been overgrown by other strains (CONEDERA et al., 2004). This statement might explain the low percentage of strains carriers of virulence genes observed in this work.

According to Paneto et al. (2007), CNF-producing E. coli (NTEC) have been rarely found in Brazil. However, $7.81 \%$ of the strains analyzed in this study were carriers of the $\operatorname{cnf} 2$ gene. NTEC strains have been associated with outbreaks and sporadic cases of diarrhoea in newborn children and adults (QUINTO; CEPEDA, 1997).

CNF2-producing strains have been isolated from calves with diarrhoea, septicaemic lambs, healthy cows and calves (BLANCO et al., 1998), and bovine clinical mastitis (RIBEIRO et al., 2002).

Therefore, the presence of CNF2-positive E. coli observed in this study could be related to the use of milk contaminated during milking process or originated from mammary quarters afflicted by mastitis in the production of the raw-milk cheeses subsequently employed in grated cheese manufacturing. This finding represents health hazard for customers and substantiates the need of implementation of hygienic measures in the production of this food.

\section{Conclusions}

Our study demonstrated low prevalence of virulence genes, which are associated with the pathogenesis of diarrhoea, in E. coli strains isolated from grated cheese. The presence of CNF-2 gene and the possibility of occurrence of other virulence factors that were not analysed in this study suggest risks of contamination in grated cheese sold in farmer's markets.

\section{References}

BEUTIN, L. et al. Identification of human-pathogenic strains of shiga toxin-producing Escherichia coli from food by a combination of serotyping and molecular typing of shiga toxin genes. Applied and Environmental Microbiology, v. 73, n. 15, p. 4769-4775, 2007.
BLANCO, M. et al. Distribution and characterization of faecal necrotoxigenic Escherichia coli CNF1+ and CNF2+ isolated from healthy cows and calves. Veterinary Microbiology, v. 59, p. 183$192,1998$.

BRANT, L. M. F. et al. Avaliação da qualidade microbiológica do queijo-de-minas artesanal do Serro-MG. Arquivo Brasileiro de Medicina Veterinária e Zootecnia., v. 59, n. 6, p. 1570-1574, 2007.

BRASIL. Portaria n. 357, de 04 de Setembro de 1997. Regulamento Técnico para Fixação de Identidade e Qualidade de Queijo Ralado. Diário Oficial [da] República Federativa do Brasil, Brasília, DF, 08 set. 1997, Seção 1, p. 19688.

CLARK, C. G. et al. PCR for detection of $c d t-I I I$ and the relative frequencies of cytolethal distending toxin variant-producing Escherichia coli isolates from humans and cattle. Journal of Clinical Microbiology, v. 40, n. 7, p. 2671-2674, 2002.

COBBOLD, R.; DESMARCHELIER, P. Characterisation and clonal relationships of Shiga-toxigenic Escherichia coli (STEC) isolated from Australian dairy cattle. Veterinary Microbiology, v. 79, p. 323-335, 2001.

CONEDERA, G. et al. Verocytotoxin-producing Escherichia coli O157 in minced beef and dairy products in Italy. International Journal of Food Microbiology, v. 96, p. 67-73, 2004.

GONZALEZ, A. G. M. et al. Enteropathogenicity markers in Escherichia coli strains isolated from soft white cheese and poultry in Rio de Janeiro, Brazil. Food Microbiology, v. 17, p. 321-328, 2000.

HOLT, J. G.; KRIEG, N. R. Bergey's manual of systematic bacteriology. Baltimore: Williams \& Wilkins, 1984.

LE MAGREX-DEBAR, E. et al. Evaluation of biohazards in dehydrated biofilms on foodstuff packaging. International Journal of Food Microbiology, v. 55, p. 239-243, 2000.

LOGUERCIO, A. P.; ALEIXO, J. A. G. Microbiologia de queijo tipo minas frescal produzido artesanalmente. Ciência rural, v. 31, n. 6, p. 1063-1067, 2001.

PANETO et al. Occurrence of toxigenic Escherichia coli in raw milk cheese in Brazil. Arquivo Brasileiro de Medicina Veterinária e Zootecnia, v. 59, n. 2, p. 508-512, 2007.

PIMENTEL, E. F. Avaliação da rotulagem e da qualidade físicoquímica e microbiológica de queijo ralado. Ciência e Tecnologia de Alimentos, v. 22, n. 3, p. 289-294, 2002.

QUINTO, E. J.; CEPEDA, A. incidence of toxigenic Escherichia coli in soft cheese made with raw of pasteurized milk. Letters in Applied Microbiology, v. 24, p. 291-295,1997.

RIBEIRO, M. G. et al. Fator necrosante citotóxico em Escherichia coli isolada de mastite clínica bovina. Arquivo Brasileiro de Medicina Veterinária e Zootecnia, v. 54, n. 06, p. 648-650, 2002.

SALVADORI, M. R. et al. Virulence factors of Escherichia coli isolated from calves with diarrhoea in Brazil. Brazilian Journal of Microbiology, v. 34, p. 230-235, 2003.

SILVA, A. S.; LEITE, D. S. Investigation of putative CDT gene in Escherichia coli isolates from pigs with diarrhea. Veterinary Microbiology, v. 89, p. 195-199, 2002.

TOLEDO, M. R. F.; FONTES, C. F.; TRABULSI, L. R. EPM Modificação do meio Rugai e Araújo para realização simultânea dos testes de produção de gás a partir da glicose, $\mathrm{H} 2 \mathrm{~S}$, urease e triptofano desaminase. Revista de Microbiologia, São Paulo, v. 13, p. 309-315, 1982a.

TOLEDO, M. R. F.; FONTES, C. F.; TRABULSI, L. R. Um meio para a realização dos testes de motilidade, indol e lisina descarboxilase. Revista de Microbiologia, v. 13, p. 230-235, 1982b.

ZAFFARI, C. B.; MELLO, J. F.; COSTA, M. Qualidade bacteriológica de queijos artesanais comercializados em estradas do litoral norte do Rio Grande do Sul, Brasil. Ciência Rural, v. 37, n. 3, p. 862-867, 2007. 